\title{
Millî Mücadele Sürecinde Mehmed Âkif ve İstiklâl Marşı
}

\begin{abstract}
Abdullah UÇMAN*
$\ddot{O} z$

Millı̂ Mücadele aynı zamanda Türk milletinin yeryüzünde var olma savaşlarından biri durumundadır. Millî Mücadele yıllarında çoluğunu çocuğunu bırakıp Anadolu'ya geçen ve cami kürsülerinde yaptığı konuşmalarla halkı aydınlatan Mehmed Âkif, bu sırada kaleme aldığı İstiklâl Marşı ile bu mücadeleyi taçlandırmıştır. Bu yüzden İstiklâl Marşı, aynı zamanda Türk milletinin bağımsızlık, hak, iman, vatan sevgisi ve İslâmiyet gibi üstün değerlerinin ifadesidir. Bu değerler sonsuza kadar varlığını devam ettirecektir. Mehmed Âkif Kastamonu'da Nasrullah Camii' inde yaptığı konuşmada halkı birlik ve beraberliğe davet etmiş, düşmandan asla dost olamayacağını dile getirmiş, Kur'an'dan çeşitli âyetlerle düşmana karşı savaşmanın dinen farz olduğunu ifade etmiştir. Mehmed Âkif'in Sebîbürreşad'da yayımlanan bu konuşması binlerce nüsha basılarak askerlere ve Anadolu halkına dağıtılmıştır. Son derece mütevazı ve onurlu bir şahsiyet olan Mehmed Âkif, işin içine para girince "İstiklâl Marşı Müsabakası”"na katılmak istememiş, ancak para şartı ortadan kaldırılınca yazdığı şiiri gerekli mercie göndermiştir. 1924 seçimlerinde ikinci defa mebus seçilemeyince İstanbul'a geri dönen "İstiklâl Marşı”" şairi Mehmed Âkif, bu süreçte sıradan bir vatandaş muamelesine tâbi tutulur. Mehmed Âkif'in bu tarihten sonraki hayatını gurbette geçirmesi sırf bu muameleden dolayıdır.
\end{abstract}

Anahtar Kelimeler: Millî Mücadele, Mehmed Âkif, İstiklâl Marşı, vatan sevgisi, cami, bağımsızlık, zafer, ümit.

* Prof. Dr., Mimar Sinan Güzel Sanatlar Üniversitesi, Fen-Edebiyat Fakültesi, İstanbul, Türkiye.

Elmek: abdullahucman@yahoo.com

https://orcid.org/0000-0002-7827-8497. 


\title{
In the period of The Turkish War Indipendence Mehmed Âkif and The Turkish Nation Anthem
}

\begin{abstract}
The Turkish War Indipendence (Millî Mücadele) is one of the struggles of the Turkish nations survival on earth. During the years of War of Indipendence Mehmed Âkif, who left his family behind to move to Anatolia and, in there, enlightened the Muslim-Turkish people with the speeches he mode at mosque pulpits, crowded this struggle with the Turkish Nation Anthem (İstiklâl Marşı) he wrote. Therefore, the National Anthem is also a concise expression of the superior values of the Turkish nation such as indipendence, truth, faith, patriotism and Islam, which these values will continue to be in existence forever. This article on the activities of Mehmed Âkif during the years of the War of Indipendence and the main themes in the National Anthem. Mehmed Âkif, especially in the speech he gave at the Nasrullah Mosque in Kastamonu, invited the people to unity and solidarity, stated the enemy could never be friend, and by citing various verses from the Qur'an, emphasized that it was religiously obligatory to fight against the enemy. This speech of Mehmed Âkif, published in Sebîlürreşad, was printed in thousands of copies, and distributed to the Anatolian people and the soldiers fighting at the front. As a very modest and honorable person, Mehmed Âkif did not want to participate in the "National Anthem Competition" because of the money award, but when the award was removed, he sent his poem to the competition board. The poet of the National Anthem, Mehmed Âkif returned to Istanbul after he could not be elected as a deputy for the second time in the 1924 elections, and he was treated as an ordinary citizien afterwards. It is only because of this tereatment that Mehmed Âkif, spent the rest of his life abroad after this date.
\end{abstract}

Keywords: The Turkish War Indipendence, Mehmed Âkif, The Turkish Nation Anthem, patriotism, mosque, indipendence, victory, hope. 
I. Dünya Savaşı sona erdiğinde, Osmanlı Devleti'nin de dahil olduğu İttifak cephesi mağlûp olmuş, tam dört yıl boyunca Çanakkale, Galiçya ve Filistin cephelerinde kahramanca savaşan ve yer yer büyük zaferler kazanan Türk ordusu da hükmen mağlûp sayılmış ve Osmanlı hükümeti ile müttefikleri İtilâf devletleriyle sulh yapmak mecburiyetinde kalmıştı. 30 Ekim 1918'de imzalanan Mondros Mütarekesi ile Türk ordusu elindeki silâhları bırakmış ve mağlûbiyeti resmen kabul etmişti. ${ }^{1}$

Ancak Mütareke'nin imzalanmasından kısa bir süre sonra, Mütareke şartları arasında herhangi bir madde bulunmadığı halde, İtilâf devletlerine ait 55 parça gemi İstanbul Boğazı'nda demirlemiş; kısa bir süre sonra da Fransız kuvvetleri Dörtyol, Adana ve Mersin ile Urfa, Maraş ve Ayıntab'1; İtalyanlar Antalya ile Konya'ya kadar uzanan bölgeyi; Yunanlılar da Trakya'da Hadımköy'e kadar uzanan sahayı işgal ederek 15 Mayıs 1919'da İzmir'e asker çıkarmış ve Batı Anadolu'ya içlerine doğru yayılmaya başlamıştır.

Mütareke'nin hemen arkasından bu beklenmedik ve haksız işgaller üzerine memleketin dört bir yanında vatanı düşman işgalinden kurtarmak için çeşitli faaliyetler başlar. Başta İstanbul olmak üzere birçok yerde bir yandan protesto mitingleri düzenlenirken bir yandan da Anadolu'nun çeşitli vilâyetlerinde Müdafaa-i Hukuk Cemiyetleri kurulur. Vatansever Türk aydınlarının meydana getirmeğe çalıştığı birlik ve beraberlik sayesinde Türk milleti için yegâne kurtuluş yolunun yine milletten beklenmesi gerektiği görüşü benimsenir. Yunan ordusunun İzmir'e ayak basması ise, Türk milletinin uğramış olduğu büyük felâketi dayanılmaz hâle getirir. Bu işgal üzerine İstanbul'da, başta Sultanahmet olmak üzere, Fatih ve Üsküdar-Doğancılar gibi şehrin çeşitli meydanlarında düzenlenen protesto mitingleri, işgale karşı

1 Ahmet Mumcu, Tarih Açısından Türk Devriminin Temelleri ve Gelişmesi, İstanbul 1984, s. 21; Bülent Demirbaş, "Mondros Mütarekesi ve Sonrası", Tanzimat tan Cumhuriyet'e Türkiye Ansiklopedisi, C. IV, İstanbul 1985, s. 1110-1119. 
millî birlik fikrinin oluşumu hususunda görülen belli başlı faaliyetler arasında sayılabilir. $^{2}$

29 Mayıs 1453'ten beri Osmanlı Devleti'nin pâyitahtı olan İstanbul 16 Mart 1920 sabahı İtilâf devletleri askerleri tarafından fiilen işgal edilince, işgal altında eli kolu bağlı bir vaziyette oturmayı onurlarına yediremeyen vatansever Türk aydınları küçük gruplar hâlinde Anadolu'ya geçmeye başlar. İstanbul'un işgali üzerine ölüm-kalım mücadelesinin verildiği Anadolu'ya geçen yüzlerce meçhul kahraman yanında, devrin tanınmış simalarından hatıra ilk gelenler arasında Halide Edip ve eşi Dr. Adnan (Adıvar), Ruşen Eşref, Yakup Kadri, Hamdullah Suphi, Yusuf Akçura, Celâl Sâhir, Falih Rıfkı, Mehmed Âkif, Yunus Nâdi, Hüseyin Kâzım Kadri ve Veled Çelebi yer almaktadır. İsimlerini andığımız bu şahsiyetlerin her birinin Anadolu topraklarına adım attıkları günden başlayarak büyük zaferin kazanıldığ 30 Ağustos 1922'ye kadar geçen üç yıl boyunca Millî Mücadele içinde birbirinden farklı kahramanlıkları söz konusudur. Ancak burada sadece, "Bugün icmâ-1 ümmet Anadolu'dadır."” diyerek Anadolu'da başlayan mukaddes mücadeleye koşan ve bir yandan câmi kürsülerinde verdiği vaazlarla, bir yandan da kaleme aldığı yazılarla Türk milletini mukaddes davaya çağıran Mehmed Âkif'in bu yıllardaki faaliyetlerini gözden geçirmeğe çalışacağız.

Mehmed Âkif'in bu yıllara ait şiirlerini kronolojik sıra dahilinde ele aldığımızda, onun, 1918 yılından itibaren büyük bir karamsarlığa kapıldığ dikkati çeker. $\mathrm{Bu}$ karamsarlıkta, memleketin ve milletin içine düştüğü perişan manzarayla birlikte yıllardır arzu ettiği ve canla başla gerçekleşmesi için çalıştı̆̆ İttihad-1 İslâm idealinin de fiilen iflâs etmesi ve artık İslâm âleminin gözle görülür bir şekilde parçalanmaya ve dağılmaya yüz tutması söz konusudur. Onun, Gölgeler'in başına aldığı Ekim 1919 tarihini taşıyan

223 Mayıs 1919 günü düzenlenen Sultanahmet Mitingi'nde okunan bildiriler için bk. Devrin Yazarlarının Kalemiyle Millî Mücadele ve Gazi Mustafa Kemal (haz. Mehmet Kaplan, İnci Enginün, Birol Emil, Necat Birinci, Abdullah Uçman), C. I, İstanbul 1981, s. 89-109. Sultanahmet Mitingi için şöyle bir el ilânı dağıtılmıştır: "Müslüman! Yedi asırlık bir saltanatın taksim olunduğunu görüyorsun! Şu hicranlı günlerimizde birleşmeğe, anlaşmağa her hususta ihtiyacın var. İşini, gücünü bırak, Cuma namazından sonra Sultanahmet’teki içtimâa koş; kadın, erkek, çoluk çocuk, orada bulun!"

3 Sebîlürreşad, nr. 466, 13 Kânun-1 evvel 1336/1920, s. 277. 
"Hüsran” adlı manzumesi, Türk milletinin ve İslâm âleminin içine düştüğü fecî manzarayı bütün çıplaklığıyla gözler önüne sermesi bakımından son derece önemlidir. ${ }^{4}$

I. Dünya Savaşı sona erip de Türk vatanının taksim edilmeye başlandığı sırada Mehmed Âkif sesinin çıktığı kadar:

“... Türkler' in yirmi beş asırdan beri istiklâllerini muhafaza etmiş bir millet oldukları tarihen müsbit bir hakikattir. Halbuki Avrupa'da bile mebde-i istiklâli bu kadar eski zamandan başlayan bir millet yoktur. Türk için istiklâlsiz bir hayat müstahildir. Tarih de gösteriyor ki Türk, istiklâlsiz yaşayamamıştır!"’5 diye haykırmaktan geri durmaz. İzmir'in Yunan ordusu tarafından işgali üzerine yeis ve üzüntüsü son haddine varmasına rağmen ümidini asla kaybetmeyen ve Türk milletinin istiklâlden mahrum yaşayabileceğini bir an için olsun aklından geçirmeyen Mehmed Âkif, Anadolu'da başlayan Millî Mücadele'nin kısa zamanda bütün memlekete yayılacağına can u gönülden inanmaktadır.

Yakın dostu Eşref Edib'in naklettiğine göre, 1920 yılı Ocak ayının ilk haftasında bir gün büyük bir heyecanla Sebîlürreşad idarehânesine gelen Mehmed Âkif, Millî Mücadele'nin başladığı Balıkesir cephesine gideceklerini söyler ve hiç gecikmeden İstanbul'dan ayrılarak beraberce Balıkesir'e hareket ederler. ${ }^{6}$ Balıkesir cephesinde millî müdafaayı bizzat gören ve Millî Mücadele'yi "büyük bir gazâ" olarak isimlendiren Mehmed Âkif, burada büyük bir heyecanla "Zafer yolu bu yoldur!" demekten kendini alamaz. Batı Anadolu'da düşmana karşı yer yer başlayan direnme hareketlerini de desteklemek ve teşvik etmek üzere, Balıkesir'de (o günkü adıyla Karesi) 23 Ocak günü Zağanos Paşa Câmii'ni dolduran cemaatin 1srarı üzerine Cuma namazından sonra kürsüye çıkarak memleketin içine düştüğü fecî durum karşısında neler yapılabileceğini ve millet olarak ne yapılması gerektiğini veciz bir şekilde dile getirir.

4 Safahât (haz. M. Ertuğrul Düzdağ), 6. b., İstanbul 2005, s. 409.

5 "Manda Meselesi”, Sebîlürreşad, nr. 437-438, 21 Ağustos 1335/1919, s. 175.

6 Eşref Edip, Mehmet Âkif-Hayatı ve Eserleri, İstanbul 1962, s. 128-129. 
Zağanos Paşa Camii'ndeki mev'izesine:

Cihân altüst olurken seyre baktın, öyle durdun da,

Bugün bir serseri, bir derbedersin kendi yurdunda!

Hayat elbette hakkın... Lâkin, ettir haykırı ihkak,

Să̆ırdır kubbeler, bir ses duyar: Dâvâ-yı istihkak...

mısralarını okuyarak başlayan Mehmed Âkif, konuşmasında ana hatlarıyla şu noktalar üzerinde durur:

-Yeryüzündeki Müslüman milletler uzun bir zamandan beri temas hâlinde bulundukları başka milletlerin ilerleme yolunda attığı adımlarla fazla ilgilenmemiş; "umûr-1 din"e olduğu kadar "umûr-1 dünya"ya da "bîgâne" kalmıştır. Batı dünyasında büyük bir süratle gelişen teknik medeniyet harikalar yaratırken Müslümanlar bunlardan yararlanmak bir tarafa, ne olup bittiğinden bile haberdar olmamıştır. "Yeryüzünde yaşamak herkesin hakkıdır, ancak yaşamayı hak etmek gerekir."

-Batı dünyasının güçlü oluşunun temelinde birlik ve beraberlik şuuru vardır. Aynı şekilde Müslümanlar için "hakk-1 hayat" da, ancak birlik ve beraberlikle mümkün görünmektedir: "Eğer Müslümanlar yaşamak istiyorlarsa cemaat arasında nifaka, şikaka, dargınlığa, küskünlüğe, ayrılık ve gayrılığa meydan açabilecek en ufak sözlerden, en ehemmiyetsiz görünen hareketlerden bile çekinmelidirler."

-Yeis ve ümitsizliğe düşmek dinimize göre "küfür" sayılmıştır. Bunun için Müslümanların Allah'ın merhamet ve yardımından asla ümit kesmemesi, tek tek üzerlerine düşen görevleri yaptıktan sonra vaad edilen kurtuluşu beklemeleri gerekir.

-Başta din, namus ve vatan olmak üzere bütün varlığımız tehlike düşmüş, düşman kapılarımıza dayanmıştır. Bu durumda yapılacak şey, ayrılıkgayrılık gibi küçük meseleleri bir tarafa bırakmak ve el birliğiyle bu nâmert istilâyı bir an önce geri püskürtmektir. ${ }^{8}$

8 Mehmed Âkif' in burada yaptığı konuşmanın tamamı Sebîlürreşad' da yayımlanmıştır (nr. 458, 12 Şubat 1336/1920, s. 183-186). Ayrıca bk. Âlim Kahraman, Tutuşmuş Bir Yürek, Adanmış Bir Hayat-Mehmet Âkif, İstanbul 2021, s. 261-263. 
Konuşmayı dinlemek üzere Zağanos Paşa Câmii'ni dolduran binlerce Balıkesirli Müslüman büyük bir heyecan ve 1stırap içinde gözyaşı dökerken, Mehmed Âkif, Türk milleti için Allah'tan sabır, sebat, zafer ve yardım dileyerek kürsüden iner. Bu konuşmayı yaptıktan sonra Balıkesir'de birkaç gün daha kalır; bir süre yine cephede kahramanca çarpışan mücahitlerle görüştükten sonra yüksek bir moralle İstanbul'a döner.

Bu sirada Anadolu'da bir yandan millî cepheler kurulmaya, millî ve mukaddes mücadele memleketin dört bir yanında varlığını hissettirmeğe başlarken, diğer yandan 23 Nisan 1920 günü Ankara'da Anadolu'daki vilâyetlerden gelen temsilcilerle işgal altındaki İstanbul'dan kaçabilen bir kısım mebusların da katılmasıyla Büyük Millet Meclisi açılır.

Osmanlı Devleti'nin altı asırlık payitahtı 16 Mart 1920 sabahı İtilâf kuvvetleri tarafından fiilen işgal edilince, şehir maddî-mânevî kasvetli bir havaya bürünür. İşgal kuvvetlerinin akla hayale sığmaz hareketleriyle artık İstanbul yaşanmaz bir hal alınca, Mehmed Âkif, yine Eşref Edib'e:

-Artık burada duracak zaman değildir, gidip çalışmak lâzım. Bizim tarafımızdan halkı tenvîre ihtiyaç varmış; çağırıyorlar, mutlaka gitmeliyiz. Ben yarın Ankara'ya hareket ediyorum. Hiç kimsenin haberi olmasın. Sen de idarehânenin işlerini derle topla, Sebîlürreşad klişesini al, arkamdan gel. Meşîhat'takilerle de temas et, Harekât-1 Milliye aleyhinde bir halt etmesinler!"’ diyerek Anadolu'da başlayan Millî Mücadele'ye fiilen katılmaya karar verir ve 1920 yılı Nisan sonlarına doğru bir sabah erkenden henüz on iki yaşındaki oğlu Emin'le birlikte İstanbul'dan ayrılır. Yol arkadaşı Ali Şükrü Bey'le Üsküdar'da buluştuktan sonra Alemdağ yoluyla deniz kıyısına varır ve buradan temin ettiği bir vasita ile İnebolu'ya geçer. İnebolu'dan da Ankara'ya hareket eder ve zorlu bir yolculuktan sonra. Mayıs başlarında Ankara'ya varır (9 Mayıs 1920). Oğlunun naklettiğine göre, Ankara'da Meclis önünde Mustafa Kemal'le karşıllaşan Mehmed Âkif'e Mustafa Kemal:

9 Eşref Edib, Mehmed Âkif, s. 139. 
“Sizi bekliyordum efendim, tam zamanında geldiniz!” der. Mehmed Âkif Ankara’ya geldiği günlerde Hacı Bayram Câmii’nde kürsüye çıkarak Kuvâyı Milliye'nin bir İttihatçı hareketi olmadığını; üzerinde yaşadığımız vatanı kaybedersek gidecek başka bir yerimiz bulunmadığını; bu hareketin bir cihad ve bu cihada katılmanın da dinen farz olduğunu anlatır.

Mehmed Âkif Ankara'ya yerleştikten kısa bir süre sonra, Miralay İsmail Bey'in istifası üzerine, onun yerine, Meclis Reisi Mustafa Kemal'in teklifiyle Burdur mebusu seçilir. Kısa bir süre sonra da halkı cepheye ve birliği davet için önce Eskişehir'e, arkasından da oğluyla birlikte Burdur'a gider. Burada, kendisini hasret ve muhabbetle bağırlarına basan Burdur halkına da vaaz ve nasihat eder. Bu sırada dinleyiciler arasında bulunan oğlu Emin Âkif, babasının buradaki konuşmasını şu şekilde nakletmektedir:

“... Babamı ilk defa Burdur'da hükûmet konağında üç-dört yüz kişiyi mütecâviz bir cemaata karşı hitap ederken gördüm. Fazla bağırdığı zaman sertleşen gür sesiyle konuşuyor, çok heyecanlı olduğu bütün hareketlerinden belli oluyordu. İzmir havalisinden sızan kara haberleri, vatandaşlarımıza yapılan işkence ve hakaretleri, mülevves çizmeler altında çiğnenen tarihî ve ilâhî mâbedlerimizi öyle yanık bir dille ifade ediyor, bu fecâyiin yürekler acısı avâkibini öyle acı bir dille tarif ediyordu ki... Ben de dinleyiciler arasına sıkışmıştım. O muazzam kalabalık derin bir sükûta dalmıştı. Lâkin bu öyle bir sessizlik, öyle bir hava idi ki, kasırgalar koparacak ruhların kellesini koltuğuna almaya niyet eden başların son kat’î kararından doğuyordu. Bir de şurada burada hissiyâtına mâlik olamayarak hıçkırıklarını tutamayan vatanseverlerin iniltileri duyuluyordu." ${ }^{10}$

Mehmed Âkif Burdur'da bir hafta kadar kaldıktan sonra oradan Sandıklı'ya geçer ve bir gece yatsı namazını müteakip minbere çıkarak orada da aynı mahiyette bir konuşma yapar; buradan Antalya yoluyla Ankara'ya döner. Ankara'ya dönüşünden birkaç gün sonra bu defa Birinci İnönü 
Zaferi'nin müjdesi gelir. Oğlunun bildirdiğine göre, Mehmed Âkif bu habere çocuklar gibi sevinir. Bir müddet sonra, 2 Ekim 1920 tarihinde başlayıp 22 Kasım'a kadar devam eden Konya isyanının bastırılması için Ankara'dan Konya'ya gider. Daha önce Balıkesir halkına yaptığı gibi, Konya halkına da onların anlayabileceği bir dille nasihat eden Mehmed Âkif, vatanın yok olmak tehlikesiyle karşı karşıya bulunduğunu, böyle bir zamanda ayrılık-gayrılık yerine milletin tek bir vücut hâlinde birleşerek Ankara'da yeni kurulan hükûmete yardım etmeleri gerektiğini hatırlatarak isyancıları ikna etmeğe çalışır. ${ }^{11}$

Öte yandan, İstanbul'da artık rahatça çalışma imkânı kalmayınca, Eşref Edib de, daha önce Mehmed Âkif'in vermiş olduğu tâlimâta uyarak Sebîlürreşad mecmuasının başlık klişesini alır ve Karadeniz yoluyla önce İnebolu'ya, oradan da Kastamonu'ya geçerek durumu Ankara'da bulunan Mehmed Âkif'e bildirir. O da, Eşref Edib'ten aldığı haber üzerine, Meclis'in kararı ve halkı aydınlatma vazifesiyle Ankara'dan ayrılır ve 15 Ekim 1920 sabahı Kastamonu'ya gelir. Burada yine bir taraftan civar kasaba ve köyleri dolaşarak halkı aydınlatırken, bir yandan da kısa bir hazırlığı müteakip Eşref Edib'le birlikte mecmuayı bu defa Kastamonu'da yayımlamaya başlar.

Sebîlürreşad'ın Kastamonu' da yayımlanan 25 Teşrîn-i sâni 1920 tarihli ilk sayısında, mecmuanın niçin Anadolu’ya nakledildiği şu şekilde açıklanır:

"İngilizler merkez-i hilâfeti işgal ile zulüm ve tazyiklerini arttırdılar. Maddî, mânevî bütün hürriyet-i İslâmiye’yi selbettiler. Her şeyi tahakküm ve iradeleri altına aldılar. Bunun üzerine Müslümanlığı ve Müslümanların hukukunu müdafaa hususunda hiçbir tesir altında kalmayarak daima istiklâl-i efkârını muhafaza etmiş bulunan Sebîlürreşad'ın İstanbul'da intişârına imkân kalmadı. Onun için inâyet-i Hak'la risâlemizi bugünden itibaren Anadolu'da neşretmeğe başlıyoruz." "12

11 Eşref Edib, Mehmed Âkif, s. 142.

12 Sebîlürreşad, nr. 464, 25 Teşrîn-i sâni 1336/1920, s. 264. 
Mehmed Âkif Kastamonu'da bir yandan Sebîlürreşad'1 yayımlamayı sürdürürken, bir yandan da Anadolu'da başlayan Millî Mücadele hakkında halkı aydınlatmak ve halka moral vermek ihtiyacını hisseder. Bunun için, yine en tesirli yol olarak câmi kürsülerinden konuşmalar yapmaktır. Kastamonu'ya gelişinden sonraki ilk Cuma günü Nasrullah Câmii kürsüsüne çıar. Mehmed Âkif burada yaptı̆̆ konuşmada, cemaatin kolayca anlayabileceği bir şekilde Sevr muahedesinin Türk milleti için bir ölüm fermanı olduğunu, bunu kabul etmenin esareti ve yok olmayı kabul etmek demek olduğunu izah ederek Türk yurdunun geçirmekte olduğu tehlikeyi yine son derece net bir şekilde gözler önüne serer.

Mehmed Âkif buradaki konuşmasına önce Kur'ân-ı Kerîm'deki Âl-i İmran, Tevbe, Bakara ve Mâide sûrelerinden bir kısım âyetler okuyarak ana hatlarıyla şu hususlar üzerinde durur:

-Düşmandan asla dost olmaz, düşman hiçbir zaman "mahrem-i esrâr" kabul edilemez. Türk milleti arasında öteden beri yaygın olan "İngiliz adaleti", "Fransız hamiyeti", “Alman dehâsı", "İtalyan terakkiyâtı" gibi sloganlar asla itibar edilmemesi gereken, gerçek dışı sözlerdir. Mehmed Âkif’e göre: "Avrupalıların ilimleri, irfanları, medeniyetleri, sanâyideki terakkîleri inkâr olunur şey değildir. Ancak insaniyetlerini, insanlara karşı olan muamelelerini kendilerinin maddiyattaki terakkileriyle ölçmek kat'iyyen doğru değildir.”

-S1k sık vicdan hürriyetinden bahseden Batılılar aslında dünyanın en mutaassıp cemaatidir. Bu yüzden, çocukları doğar doğmaz dinî ve millî telkinatla büyütülen, bilhassa Müslümanlara karşı büyük bir düşmanlık hissiyle yetiştirilen bir Hıristiyan'1n bir Şarklıyı, hele bir Müslüman'1 sevmesine imkân ve ihtimal yoktur.

-Müslümanların en büyük düşmanı fitne, fesat, nifak ve şikaktır; bu kötü hasletler yüzünden Emevîler'den başlayarak Abbâsîler, Endülüslüler, Gazneliler ve Selçuklular saltanatlarını, Osmanlılar ise eski büyüklüklerini kaybetmiştir. Avrupa medeniyetine erişebilmek için yapılacak tek şey, önce, aramıza sokulan fitne ve fesadı ortadan kaldırarak baş başa verip çalışmaktır. 
-Düşmanın bizden istediği, herhangi bir vilâyet veya sancak değil, doğrudan doğruya başımız, boynumuz, hayatımız, saltanatımız, devletimiz, hilâfetimiz, dinimiz ve imanımızdır. Bu yüzden, artık aklımızı başımıza almanın zamanı gelmiştir; çünkü artık "çekilip gitmek için arka tarafta bir karış yerimiz yoktur!"

-Yeis ve ümitsizlik, hele Allah’tan ümidi kesmek, dinimizde küfür ile bir tutulmuştur. Dünyada güvenilecek ve dayanılacak yegâne şey, Cenâb-1 Hakk'ın inâyet ve merhametidir.

-Müslümanlar önce azim ile, sonra da tevekküle memurdur. Yeise kapılmayarak çalışan bir Müslüman için aşılamayacak bir engel, varılamayacak bir gaye yoktur.

-Mensubu olmakla şeref duyduğumuz İslâm dini, zillet, meskenet ve sefalet dini değildir. Müslüman yurtları düşman çizmeleri altında inlerken elikolu bağlı bir vaziyette oturan Müslümanlar, "Müslümanların derdini kendine dert etmeyen Müslüman değildir!” diyen Hz. Peygamber'in huzuruna acaba nasıl çıkacaktır?

-Uğramış olduğumuz bu felâketler, dine olan bağlılı̆̆ımızın zayıflamasından dolayıdır. İslâmiyet kolaylık dinidir, Cenâb-1 Hak bize takatimizin üstünde bir şey teklif etmemiştir. Hayattan maksat, insanca yaşamak ve Allah’ın rızasını kazanarak öteki âleme gitmektir.

-Müslümanlar, bilhassa Anadolu'da yaşayan Müslüman-Türkler birbirlerinin dertlerinden haberdar bile olamayacak kadar hissiz bir hâle gelmiştir. Yunan çeteleri Batı Anadolu'yu yakıp yıkarak ilerlerken bazı "sersemler”, "Halîfe ordusu geliyormuş!" diye onları karşılamaya bile hazırlanmaktadır.

-Dünya üzerinde henüz istiklâline sahip yegâne "hükûmet-i İslâmiye" Türkiye'dedir; fakat Türk milletinin tarih, namus, şan ve şerefi ayaklar altına alınmak üzeredir. Bunun için fertler arasındaki birlik ve beraberliği sarsacak en küçük hareketlere dahi meydan vermemek gerekir. 
Konuşmasında, Türk milletinin ezelî düşmanlarının sulh antlaşması ile takip ettikleri zulüm ve imha planını bütün ayrıntılarıyla açıklayan Mehmed Âkif, ayrılık ve gayrılığı şiddetle kınayarak halkı birlik ve beraberliğe davet eder.

Mehmed Âkif'i can kulağıyla dinleyen cemaat, câmi kürsüsünde ilk defa dinlediği böyle bir konuşma karşısında heyecan içinde âdeta donup kalır. Daha sonra Sebîlürreşad'da da yayımlanan bu vaaz metni ile Sevr antlaşmasının mahiyeti ve ihtiva ettiği hükümler çok açık bir şekilde tahlil edilmiş ve meselenin gerçek yüzü herhangi bir yanlış anlamaya meydan vermeyecek şekilde izah edilmiştir. ${ }^{13}$ Derginin on bir sayfasını kaplayan bu konuşma, İstiklâl Savaşı'nın ruhunu ve neden yapıldığını açıklayan en önemli belgelerden biridir.

Mehmed Âkif' in gayet veciz şekilde açıkladığı durum karşısında ortalıkta âniden bir heyecan dalgası meydana gelir ve cemaat âdeta kendinden geçerek hüngür hüngür ağlamaya başlar. Bu arada Mehmed Âkif de kendinden geçer. Cemaatin arasında sessizce Âkif'i dinleyen Eşref Edib: "Cemaat ağlıyordu, ortalığı müthiş bir heyecan kaplamıştı. Üstad da kendinden geçecek derecelere gelmişti. Onun o kadar heyecanlı bir zamanını görmemiştim. Artık sesi kesiliyordu; çok yorulmuştu. Heyecanından kalbi duracak diye korkuyordum!" der. ${ }^{14}$

Mehmed Âkif, “Bizim yolumuzda çalışıp didinenlerle mücâhede edenleri muhakkak ki yollarımıza iletiriz. Hak Teâlâ iyi işler işleyenlerle beraberdir." meâlindeki Ankebût sûresinin 69. âyetini okuduktan sonra ellerini kaldırır ve: "Yâ İlâhî, bize tevfikini gönder! (...) Müslüman yurdu her yerde felâket vurdu; bir bu toprak kalıyor dinimizin son yurdu. O da çiğnendi mi, çiğnendi demek şer'-i mübîn. Hâksâr eyleme yâ Rab onu olsun!.. Velhamdülillâhi Rabbi'lâlemîn..” diyerek konuşmasını tamamlar. Duasını yapıp kürsüden indikten sonra cemaatle beraber Kastamonu sokaklarında dolaşır ve camide başlayan heyecan dalgası bir anda bütün şehre yayılır.

Mehmed Âkif'in Nasrullah Câmii'nde vermiş olduğu bu mev'izenin

13 Sebîlürreşad, nr. 464, 25 Teşrîn-i sâni 1336/1920 0 , s. 249-259. 
olumlu tesiri kısa zamanda civardaki kaza ve köylere kadar yayılınca, bu durumdan yararlanmak isteyen Ankara'daki millî hükûmet, Mehmed Âkif’e ricada bulunarak, Kastamonu civarındaki halkı da bu meselelerden haberdar etmesini ister. Mehmed Âkif de bu rica üzerine, şehrin civarındaki belli başlı kaza ve köyleri dolaşarak oralarda da halkın anlayabileceği bir dille Sevr anlaşmasının korkunç hükümleriyle düşman istilâsı karşısında Müslümanlara düşen görevleri anlatır.

Vaaz metninin yer aldığı Sebîlürreşad nüshaları o günün imkânlarına göre bol miktarda bastırılmak suretiyle Anadolu'nun çeşitli vilâyet, sancak ve kazalarındaki vali, mutasarrıf, kaymakam ve müftülere gönderilerek cephelerde ve kahvehane gibi toplantı mahallerinde yüksek sesle okunmuş, ayrıca bir kısım mahallî basın tarafından iktibas edilmiş ve müstakil kitapçıklar hâlinde bastırılarak elden ele dağıtılmıştır. ${ }^{15}$

Mehmed Âkif'in memleket çapında büyük bir heyecan uyandıran mev'izelerinin ilk yankısı el-Cezîre cephesi kumandanı Nihad Paşa'dan gelir. Nihad Paşa, o sırada Kastamonu'da bulunan Mehmed Âkif'e çektiği telgrafta şunları yazar: "Nasrullah Câmi-i şerîfinde îrâd buyurduğunuz mev'izeyi hâvî mecmuanızın ancak bir nüshası elde edilebilmiştir. Diyârbekir'in Câmi-i Kebîr'inde Cuma namazından sonra kıraat edilerek mü'minîn-i hâzıra envâr-1 mâneviyesinden hisseyâb-1 tenevvür ve tefeyyüz olmuşlardır. Fakat, bu istifade pek mahdut kalacağından cephe mıntıkasını teşkil eden Elaziz, Diyârbekir, Bitlis, Van vilâyetleri ile civar müstakil mutasarrıflıklar halkı da nasîbedâr edilmiş ve şerefiyle hukuku doğrudan doğruya zât-1 âlînize ait olmak üzere Diyârbekir Vilâyet Matbaası'nda tab' ve teksîr edilerek bütün cepheye tevzî olunmuştur. Cenâb-1 Hak mesâil-i din ve vatan-perverânenizi meşkûr eylemesi temennisi ile ihtirâmâtımı takdim eylerim!" el-Cezîre kumandanı Nihad. ${ }^{16}$

Bu telgraftan da anlaş1lacağ 1 gibi, Mehmed Âkif'in düşman çizmeleri altındaki son Türk vatanının kurtuluşu uğrunda ailesini, çoluk-çocuğunu 
ve refahını terk ederek Anadolu'daki mukaddes mücadeleye katılması ve bu münasebetle vermiş olduğu mev'izeler, gerek halkın, gerekse cephede çarpışan kahraman Türk askerlerinin mâneviyatını yükseltmede büyük bir tesir göstermiştir.

Mehmed Âkif de, bu telgrafa cevap olmak üzere Nihad Paşa'ya şu telgrafı çeker:

“Diyârbekir'de el-Cezîre kumandanı Nihad Paşa Hazretleri’ne: Hakk-1 âcizânemdeki teveccühât-1 devletlerine an-samimi'l-kalb teşekkür ederim. Nasrullah Camii kürsüsündeki mev'izemin o havâlide ve o cephedeki bütün dindaşlarımıza tebliğine himmet ve delâlet cidden sezâvâr-1 minnettir. Cenâb-1 Hak pek kıymetli bir rüknü bulunduğunuz kahraman ordumuzu zaferden zafere îsâl ve ümmet-i İslâmiye'de belirmeye başlayan intibâhı müzdâd buyursun, âmin!" Mehmed Âkif- 16 Şubat $337^{17}$

Mehmed Âkif Kastamonu'da yaklaşık bir ay kalır ve bu süre zarfında şehir merkezi ile birlikte civardaki kaza ve köyleri de dolaşarak halkla sohbetler yapar, onları millî uyanışa katılmaya teşvik eder. 25 Aralık 1920 tarihinde de, mecmuanın başlık klişesini alarak Eşref Edib'le beraber Ankara'ya hareket eder. Bin türlü güçlük ve imkânsızlıkla ağır kış şartları altında Ilgaz Dağları'nı aşarak Ankara'ya ulaşabilir.

Millî Mücadele'nin bütün şiddetiyle devam ettiği, cephelerden birbirinden farklı haberlerin geldiği, Türk milletinin ölüm-kalım mücadelesinin yaşandığı bu günlerde Mehmed Âkif'in zihninde, bir millî marş yazma fikri uyanır. Yakınlarının ifadesine göre, yavaş yavaş şekillenmeye başlayan bu fikir, Kastamonu'dan Ankara'ya döndükten sonra, ikamet ettiği Tâceddin Dergâhı'nda vecd içinde geçirdiği gecelerde giderek olgunlaşır.

Yine bu sırada, Dârü'l-umûr-1 Askeriye'nin teklifi üzerine, Maarif Vekâleti tarafından millî marş için açılan müsabakaya tam 724 şiir gelir, ama 
jüri tarafından, bunların içinden altı şiir dışında, hiçbiri beğenilmez. ${ }^{18}$ Devrin Maarif Vekili Hamdullah Suphi'nin (Tanrıöver), millî marş için konulan para şartını ortadan kaldırması üzerine, Mehmed Âkif' in günlerdir uğraştığı şiir son şeklini alır. Daha önce 724 şiir arasından seçilen altı şiirle birlikte Mehmed Âkif' in imzasız olarak teslim ettiği şiir, önce cephedeki askerlere dağıtılır. Bunlar arasında, Millî Mücadele'nin ruhuna en uygun olan Mehmed Âkif'in kaleme aldığ1 "İstiklâl Marşı", nihayet 12 Mart 1921 günü, Türkiye Büyük Millet Meclisi kürsüsünden, aynı zamanda ünlü bir hatip olan Hamdullah Suphi tarafindan okunmak suretiyle, mebusların onayına sunulur ve neticede şiir meclisin büyük çoğunluğu tarafından ayakta alkışlanmak suretiyle, Türk milletinin millî marşı olarak kabul edilir. ${ }^{19}$

İstiklâl Marşı, ilk önce, "Kahraman Ordumuza" ithafiyla, 17 Şubat 192'de Sebîlürreşad'da, dört gün sonra da Kastamonu'da çıkan Açıksöz gazetesinde yayımlanır. Millî Marş olarak Türkiye Büyük Millet Meclisi tarafindan kabulünden sonra da, Ankara'da millî hükümetin yayın organı olan Hâkimiyet-i Milliye'nin 14 Mart 1921 tarihli 132. sayısında yayımlanmak suretiyle resmen yürürlüğge girer.

Henüz Sakarya Muharebesi'nden önce, İstiklâl Savaşı'nın o karanlık günlerinde:

Doğacaktır sana va'dettiği günler Hakk'ın,

Kim bilir belki yarın, belki yarından da yakın.

diyerek, milletin önünde aydınlık ufuklar açan Mehmed Âkif’e, yakın dostlarından Midhat Cemal Kuntay, bir gün: "Üstadım, siz inanmadığınız bir konuda kesin konuşmazsınız; nasıl oldu da burada, zaferin çok yakın

\footnotetext{
18 Müsabakaya katılanlar arasında Servet-i Fünun edebiyatının önde gelen ismi Cenab Şahabeddin ile yine Servet-i Fünunculardan Hüseyin Cahid'in kardeşi Hüseyin Suad (Yalçın) ve "Bingöl Çobanları" şairi Kemalettin Kâmi (Kamu) de vardir.

19 İstiklâl Marşı ile ilgili olarak şimdiye kadar pek çok değerlendirme ve tahlil yapılmıştır; burada bunlardan önemli bulduğumuz sadece birkaçını zikrediyoruz: Mehmet Kaplan, "50. Yılında Türk İstiklâl Marşı”, Hisar, sayı 88, Nisan 1971, s. 4-6; a. y., "İstiklâl Marşı", Millî Kültürr, sayı 9, Eylül 1977, s. 6-9; Nihad Sami Banarlı, "İstiklâl Marşı" (1-2), Kültür Köprüsü, İstanbul 1985, s. 332-340; Recep Duymaz, Millî Mücadelemiz ve İstiklâl Marşımız, İstanbul 2008, s. 29-55; İsmail Kara, Bir Düşünce Tarihi Metni Olarak İstiklâl Marşs, İstanbul 2021. Ayrıca bk. A. Azmi Bilgin, "İstiklâl Marş1 Bibliyografyası", Mehmed Âkif Ersoy (haz. Mustafa İ. Uzun), Ankara 2011, s. 212-214.
} 
olduğunu müjdelediniz?” deyince; Âkif şu cevabı verir: “Cenâb-1 Hakk’ın inâyeti ve ordularımızın başındaki kumandanların gayreti ile, düşman karşısında kesin bir galibiyet kazanacağımıza cân u gönülden inanmasam öyle yazmazdım!" der.

Millî marşların bir özelliği, içinden doğduğu milletin yaşamış oyduğu olağanüstü hâli yansıtmasıdır. Türk İstiklâl Marşı’nın kaleme alındığı günler, yukarıda belirttiğim gibi, Millî Mücadele'nin en kritik günleridir. Türk milleti bu sırada korku, ümit, yeis, zafer ve sevinç duygularıyla heyecanlarını peşpeşe ve birbirine karışmış bir halde yaşıyordu. Her mısraını dikkatle ve üzerinde düşünerek okuduğumuzda, bütün bu duyguların, İstiklâl Marşı'nda en güzel şekilde ortaya konulmuş olduğuna şahit oluruz. Bu şiir ile Türk milleti var olma azmini ve iradesini yeniden kazanmış bulunmaktadır. Ancak bu marş, yazıldığ1 o kara günleri değil, aynı zamanda Türk millî varlığının üstün meziyetlerini de en veciz bir şekilde yansıtan bir ayna gibidir. ${ }^{20}$

İstiklâl Marşı'nın ifade ettiği üstün değerler istiklâl, yani bağımsızlık, hak, iman, vatan ve İslâmiyet'tir; bu değerler dün olduğu gibi bugün ve yarın da, ebediyete kadar varlığını devam ettirecektir. Yüz yıl öncesinden bugüne, en ücra köşelerine kadar memleketimizin her tarafında, yurt dışındaki temsilciliklerimizde hemen her gün ve her türlü vesileyle okunan İstiklâl Marşı'na, zaman zaman bazı eleştiriler yöneltilmiş ve yeni bir marş yazılması yolunda birtakım teklifler yapılmışsa da, 1982 Anayasası'nın 3. maddesine “Türkiye Cumhuriyeti’nin millî marşı İstiklâl Marşı'dır” ibaresi ilâve edilmek suretiyle, bu ve benzeri itirazların önü alınmıştır.

"İstiklâl Marşı” için, "O artık benim değildir, milletimindir! Benim milletime karşı en kıymetli hediyem budur!” diyerek, Safahât'a dahil etmeyen Mehmed Âkif, ölüm döşeğinde: "İstiklâl Marşı... O günler ne samimi, ne heyecanlı günlerdi. O şiir, milletin o günkü heyecanının ifadesidir. Bin bir

20 İstiklâl Marşı'nın kabulünün 90. yıldönümü dolayısıyla yayımlanan İstiklâl Marşı İstikbal Marşl-41 Dize 41 Yorum adlı kitapta, şiirin her mısraı, çoğu akademisyen, 41 kişi tarafından ayrı ayrı ele alınıp yorumlanmıştır (ed. Hasan Akay-M. Fatih And, İstanbul 2010). 
fecâyî karşısında bunalan ruhların, 1stıraplar içinde halâs dakikalarını beklediği bir zamanda yazılan o marş, o günlerin kıymetli bir hâtırasıdır.. O şiir, bir daha yazılamaz. Onu kimse yazamaz... Onu ben dahil bir daha hiç kimse yazamaz; onu yazabilmek için o günleri görmek, o günleri bizzat yaşamak lâzımdır... Allah, bu millete bir daha İstiklâl Marşı yazdırtmasın!” diyerek bu fâni âleme veda eder.

Millî Mücadele'nin devam ettiği üç y1l boyunca bizzat bu mücadelenin içinde yer alan binlerce isimsiz kahramanla birlikte verdiği şerefli hizmetlerin yanında bu mücadelenin 1stırap, ümit ve heyecanıyla Türk edebiyatına başta "İstiklâl Marşı" olmak üzere, "Ordunun Duası", "Bülbül” ve "Leylâ" gibi ölümsüz eserler hediye eden Mehmed Âkif, Mayıs 1923’te İstanbul'a dönerken Millî Mücadele hâtırası olarak yanında bir istiklâl madalyası ile Türkiye Bülük Millet Meclisi âzâlarına verilen bir mavzer tüfeği getirir. Ölünceye kadar yanından ayırmadığı bu madalya ile tüfeğe ayrı bir ihtimam gösteren Mehmed Âkif için bu madalya ile silâh, herhalde, Millî Mücadele yıllarındaki unutulmaz hizmetlerinin en değerli hâtırası idi. ${ }^{21}$

\footnotetext{
21 İstiklâl Marşı'nın Türkiye Büyük Millet Meclisi tarafından kabulünün 100. yılı olan 2021 yılının T. C. Cumhurbaşkanlığı tarafından "İstiklâl Marşı ve Mehmed Âkif Yıllı" olarak ilân edilmesi münasebetiyle Mehmed Âkif'le ilgili birçok yayın yapılmıştır; ancak ben burada bunlardan birkaçını zikretmek istiyorum: Otuz kadar akademisyen ve araştırmacının yazılarıyla Mustafa İsmet Uzun'un editörlüğünde hazırlanan, T. C. Kültür ve Turizm Bakanlı̆̆ı tarafından ilk baskısı 2011 yılında yapılan Mehmed Âkif Ersoy adlı prestij kitabın bir kısım ilâvelerle, geçtiğimiz aylarda üçüncü baskısı yapıldı. Âlim Kahraman'ın Tutuşmuş Bir Yürek Adanmış Bir Hayat Mehmet Âkif adlı, çok yönlü ve ayrıntılı Âkif biyografisi ile Ahmed Güner Sayar'ın yıllardır üzerinde çalıştı̆̆ı Çekiç İle Örs Arasında Mehmed Âkif Ersoy adıyla yayımlanan çalışması, Zeytinburnu Belediyesi Kültür Daire Başkanlığı tarafından yayımlanan Mebus ve Şair Mehmet Âkif Ersoy ile Diyanet İşleri Başkanlığı tarafından yayımlanan Mehmed Âkif Ersoy ve İstiklâl Marşı, bu yılın dikkati çeken eserleri arasında yer alıyor. İsmail Kara'nın, Bir Düşünce Tarihi Metni Olarak İstiklâl Marşs adlı kitabı ise, ayrı bir öneme sahip bulunuyor. "Mehmet Âkif Fikir ve Sanat Vakfı" ile M. Rüyan Soydan'ın himmetiyle ilk sayısı önceki yıl çıkan Âkif Salnâmesi'nin, Burdur Mehmet Âkif Ersoy Üniversitesi'nin katkılarıyla hazırlanıp basılan ikinci sayısı da, Mehmed Âkif'le ilgili yeni araştırmalar itibariyle önem arz ediyor.
} 


\section{Kaynakça}

Akay, Hasan-And1, M. Fatih (2010), İstiklâl Marşı-İstikbal Marşı:41 Dize 41 Yorum, İstanbul: 3 F Yayınları.

Banarlı, Nihad Sami (1985), “İstiklâl Marşı” (1-2), Kültür Köprüsü, s. 332-340, İstanbul: Kubbealtı Yayınları.

Bilgin, A. E-Azmi (2011), "İstiklâl Marşı Bibliyografyası”, s. 212-214, Mehmet Âkif Ersoy (haz. Mustafa İ. Uzun), Ankara: T. C. Kültür Bakanlığı Yayınları.

Demirbaş, Bülent (1985), "Mondros Mütarekesi ve Sonrası", Tanzimat'tan Cumhuriyet'e Türkiye Ansiklopedisi, C. IV, s. 1110-1119, İstanbul: İletişim Yayınları.

Duymaz, Recep (2008), Millî Mücadelemiz ve İstiklâl Marşımız, İstanbul: 3 F Yayınları.

Edip, Eşref (1962), Mehmet Âkif-Hayatı ve Eserleri, İstanbul: Âsâr-1 İslâmiye Kütüphanesi Neşriyatı.

Ersoy, Emin Âkif (1948), “Safahât Şairini Oğlundan Dinleyiniz”, Millet, nr. 107, s. 16, İstanbul. Ersoy, Mehmet Âkif (2005), Safahât (haz. M. Ertuğrul Düzdağ), İstanbul: MED Yayınları.

Kahraman, Âlim (2021), Tutuşmuş Bir Yürek, Adanmış Bir Hayat, İstanbul: Büyüyen Ay Yayınları.

Kaplan, Mehmet (1971), “50 Y1lında Türk İstiklâl Marş1”, Hisar, sayı 88, s. 4-6, Ankara.

Kaplan, Mehmet (1977), “İstiklâl Marş1”, Millî Kültür, sayı 9, s. 6-9, Ankara.

Kaplan, Mehmet- Enginün İnci-Emil, Birol-Birinci, Necat-Uçman, Abdullah (1981), Devrin Yazarlarının Kalemiyle Milli Mücadele ve Gazi Mustafa Kemal, C. I, İstanbul: T. C. Kültür ve Turizm Bakanlığı Yayınları.

Kara, İsmail (2021), Bir Düşünce Tarihi Metni Olarak İstiklâl Marşı, İstanbul: Dergâh Yayınları.

Mumcu, Ahmet (1984), Tarih Açısından Türk Devriminin Temelleri ve Gelişmesi, İstanbul: İnk1lâp Kitabevi.

Sayar, Ahmed Güner (2021), Çekiç İle Örs Arasında Mehmed Âkif Ersoy, İstanbul: Ötüken Yayınları.

Sebîlürreşad (1919), nr. 437-438.

Sebîlürreşad (1920), “Zağanos Paşa Konuşması”, nr. 458.

Sebîlürreşad (1920), "Nasrullah Camii Konuşması”, nr. 464.

Sebîlürreşad (1921), "Haber”, nr. 468. 